\title{
Volcanic style in the Strand Fiord Formation (Upper Cretaceous), Axel Heiberg Island, Canadian Arctic Archipelago
}

\author{
B. RICKETTS, K. G. OSADETZ AND A. F. EMBRY
}

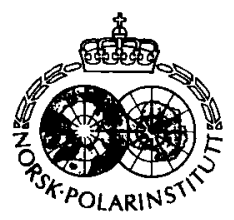

Ricketts, B., Osadetz, K. G. \& Embry, A. F. 1985: Volcanic style in the Strand Fiord Formation (Upper Cretaceous), Axel Heiberg Island, Canadian Arctic Archipelago. Polar Research 3 n.s., 107-122.

The Strand Fiord Formation is a volcanic unit of early Late Cretaceous age which outcrops on west-central and northwestern Axel Heiberg Island in the Canadian Arctic Archipelago. The formation is part of the thick Sverdrup Basin succession and immediately precedes the final basin foundering event. The Strand Fiord volcanics are encased in marine strata and thin southward from a maximum thickness of $789+\mathrm{m}$ on northwestern Axel Heiberg to a zero edge near the southern shore of the island. Tholeiitic icelandite flows are the main constituent of the formation with volcaniclastic conglomerates, sandstones, mudrocks and rare coal seams also being present. The lava flows range in thickness from 6 to $60 \mathrm{~m}$ and subaerial flows predominate. Both pahoehoe and aa lava types are common and the volcanic pile accumulated mostly by the quiet effusion of lavas. The volcaniclastic lithologies become more common near the southern and eastern edges of the formation and represent lahars and beach to shallow marine reworked deposits. The Strand Fiord volcanics are interpreted to represent the cratonward extension of the Alpha Ridge, a volcanic ridge that was active during the formation of the Amerasian Basin.

B. Ricketts, K. G. Osadetz and A. F. Embry, Geological Survey of Canada, 3303-33rd St. N.W., Calgary, Alberta T2L 2A7, Canada; August 1984 (revised October 1984).

\section{Introduction}

The Sverdrup Basin was the main depocentre in the Canadian Arctic Archipelago from Early Carboniferous to early Tertiary (Fig. 1). The basin centre is located near west-central Axel Heiberg Island where the stratigraphic succession is about
13,000 $\mathrm{m}$ thick (Balkwill 1978). The basin developed upon highly deformed Lower Paleozoic strata and originated by rifting in Carboniferous time (Balkwill 1978). Upper Paleozoic strata consist of shallow water carbonates and clastics around the basin edge with deeper water clastics, carbonates and evaporites in the basin centre.

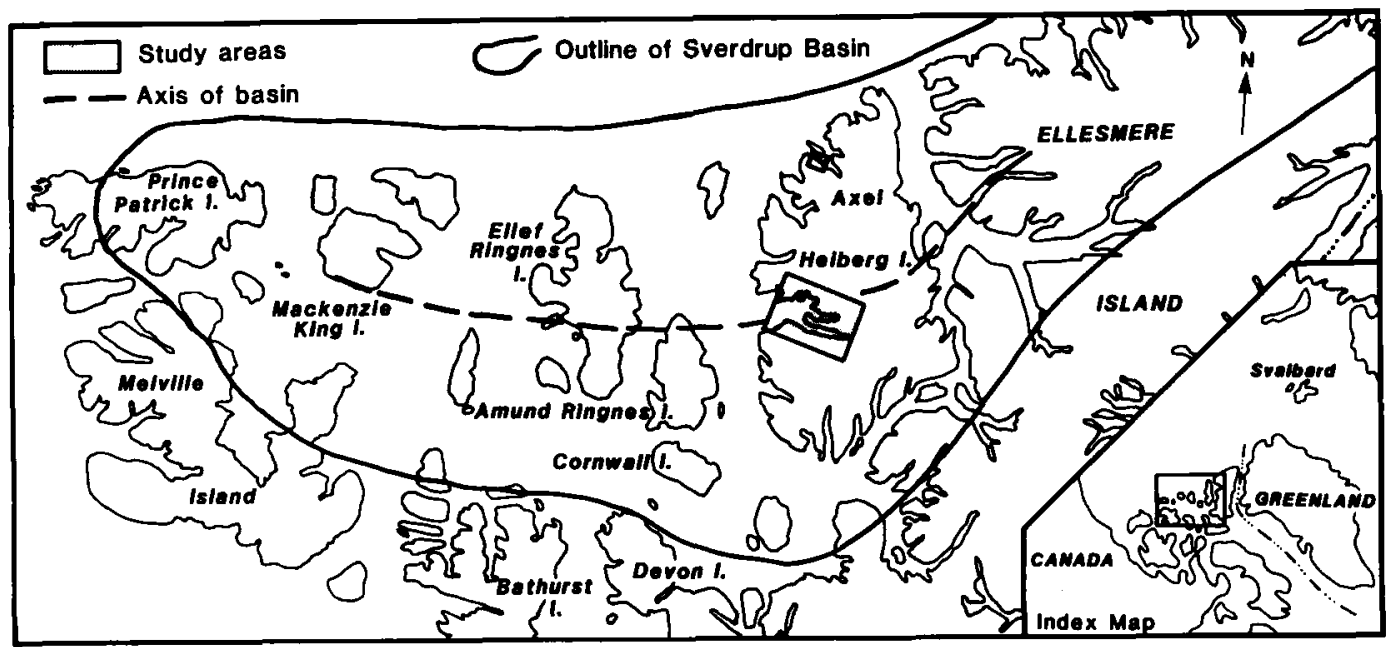

Fig. 1. Outline of Sverdrup Basin in the Canadian Arctic Archipelago and location of study areas. 
The Mesozoic succession consists almost entirely of clastic strata with large deltaic complexes present at various intervals. Balkwill (1978) has provided a concise account of the stratigraphic development of the Sverdrup Basin and the reader is referred to that paper for further details.

Basaltic volcanism and intrusion occurred at several times in the evolution of the Sverdrup Basin: Late Carboniferous, Early Permian, Early Cretaceous and late Cretaceous. These igneous events appear to be related to the initial and subsequent rifting events in the basin history and mark times of significant change in basin evolution
(Balkwill 1978). Despite the importance of the volcanic strata in basin evolution scant attention has been paid to them. This paper provides an irterpretation of the youngest suite of volcanic strata in the Sverdrup Basin, the Strand Fiord Formation. These volcanics and associated intrusions herald the final basin foundering event of early Late Cretaceous age. This was followed by basin infilling with clastic sediments of the Kanguk and Eureka Sound formations in the late Late Cretaceous and early Tertiary, and by uplift and deformation of the basin during the early Tertiary (Eurekan Orogeny).

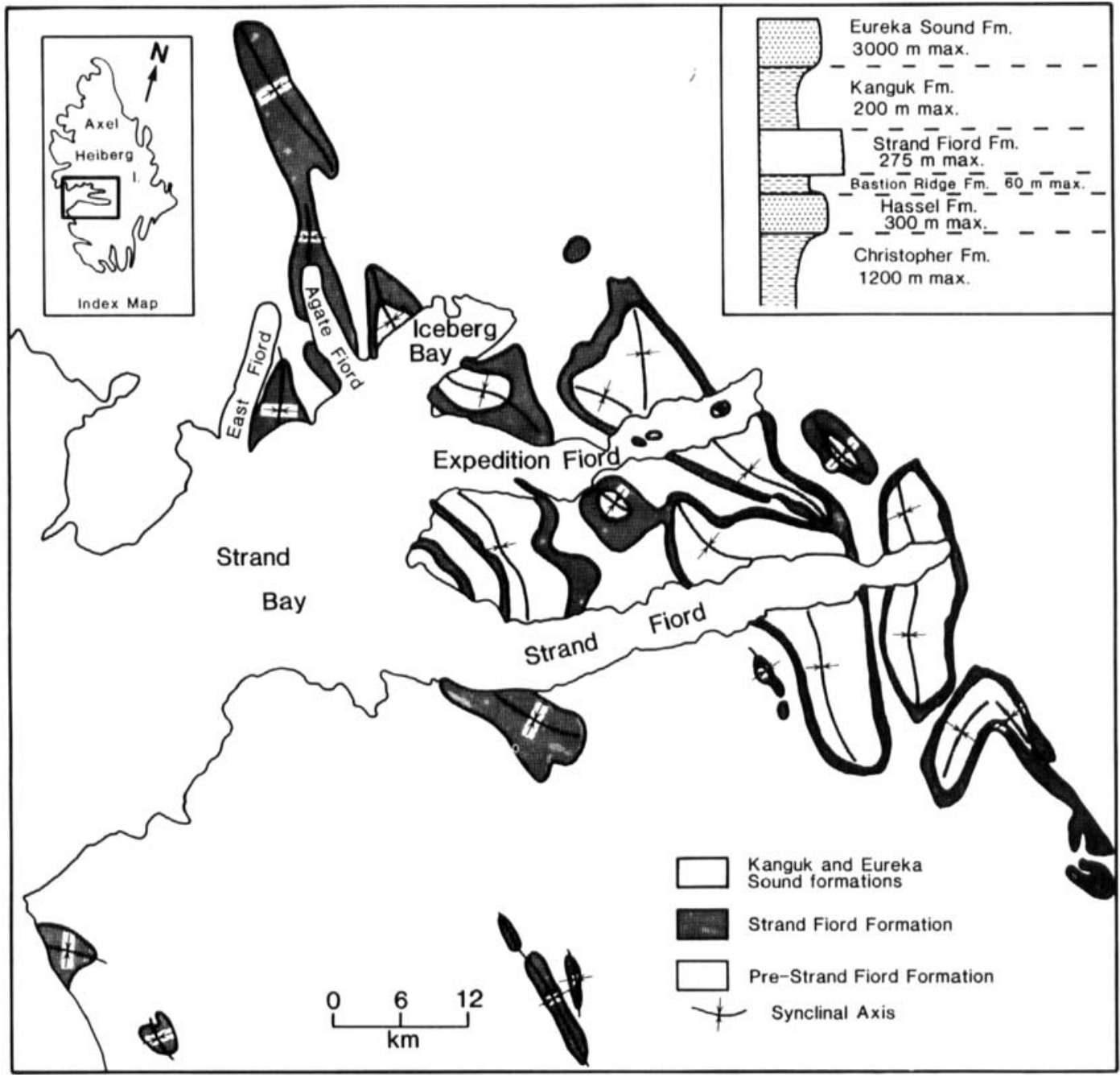

Fig. 2. Outcrop pattern of Strand Fiord Formation, west-central Axel Heiberg Island and general stratigraphic column (from Thorsteinsson, 1971a, b, c, d). 


\section{Regional stratigraphy}

The Strand Fiord Formation consists mainly of basalt flows and agglomerates and was first named by Souther (1963). He established a type section for the formation near the western tip of Kanguk Peninsula, west-central Axel Heiberg Island. At this locality the formation is $182 \mathrm{~m}$ thick. Subsequent regional mapping by $\mathrm{E}$. T. Tozer and $\mathrm{R}$. Thorsteinsson of the Geological Survey of Canada indicated that the formation is widespread on west-central Axel Heiberg Island (Thorsteinsson, 1971a, b, c, d). Figure 2 illustrates the distribution of the Strand Fiord Formation in this area. The Mesozoic and early Tertiary strata of west-central Axel Heiberg Island are folded in a series of doubly plunging synclines and anticlines. The Strand Fiord Formation occurs on the flanks or in the cores of synclines and forms resistant ridges throughout the area (Fig. 3). Excellent exposure of the volcanics is common although accessible sections are rare and most often occur along stream cuts. Reconnaissance studies of the Strand Fiord Formation in this area are by Tozer (1963) and Fricker (1963).

On west-central Axel Heiberg Island the Strand Fiord Formation conformably overlies dark grey, silty shales of the Bastion Ridge Formation and is overlain by bituminous shales of the Kanguk Formation (Fig. 2). The maximum thickness of the Strand Fiord Formation on Kanguk Peninsula is $275 \mathrm{~m}$ and the formation thins to the east and south. The formation is absent on eastern and southern Axel Heiberg Island but the actual zero edge of the formation cannot be accurately positioned due to lack of preservation of Upper Cretaceous strata over much of Axel Heiberg Island.

Recent mapping and stratigraphic studies on northern Axel Heiberg Island revealed the presence of the Strand Fiord Formation along the southern shore of Bunde Fiord (Fig. 4). These volcanic strata had previously been mapped as part of the Lower Cretaceous Christopher Formation (Thorsteinsson \& Trettin 1972). In this area the Strand Fiord Formation unconformably overlies the Hassel Formation and is the youngest stratigraphic unit preserved in the area. The preserved thickness of the formation in this area is $789+\mathrm{m}$.

Figure 5 illustrates the interpreted stratigraphic relationships of the Strand Fiord Formation on western Axel Heiberg Island. The formation is laterally equivalent to clastics of the Bastion Ridge Formation which includes an upper sandstone unit on southern Axel Heiberg Island. This sandstone unit, which is also found on Amund Ringnes Island, contains Turonian fossils (Balkwill 1983) suggesting that the Strand Fiord Formation is partly Turonian in age. The underlying Hassel Formation is considered to range in age from late Albian to early Cenomanian by Balkwill (1983) and the overlying Kanguk Formation yields Santonian pelecypods (Souther 1963). It is possible that the Strand Fiord Formation ranges in age from late Cenomanian to Coniacian ( $95-88 \mathrm{Ma})$.
Fig. 3. Ridge-forming Strand Fiord Formation on the flank of a diapir-cored anticline, south shore of Expedition Ford. S.F. - Strand Fiord Formation, B Bastion Ridge Formation, $\mathbf{H}$ Hassel Formation, C - Christopher Formation, D - diapiric anhydrite of Otto Fiord Formation.

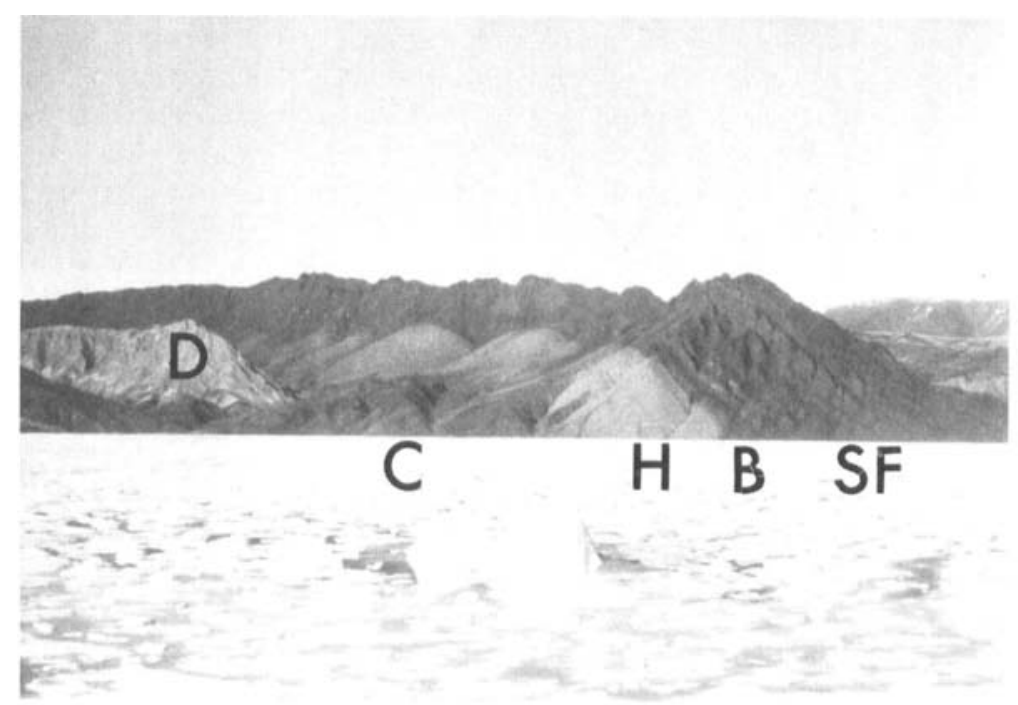




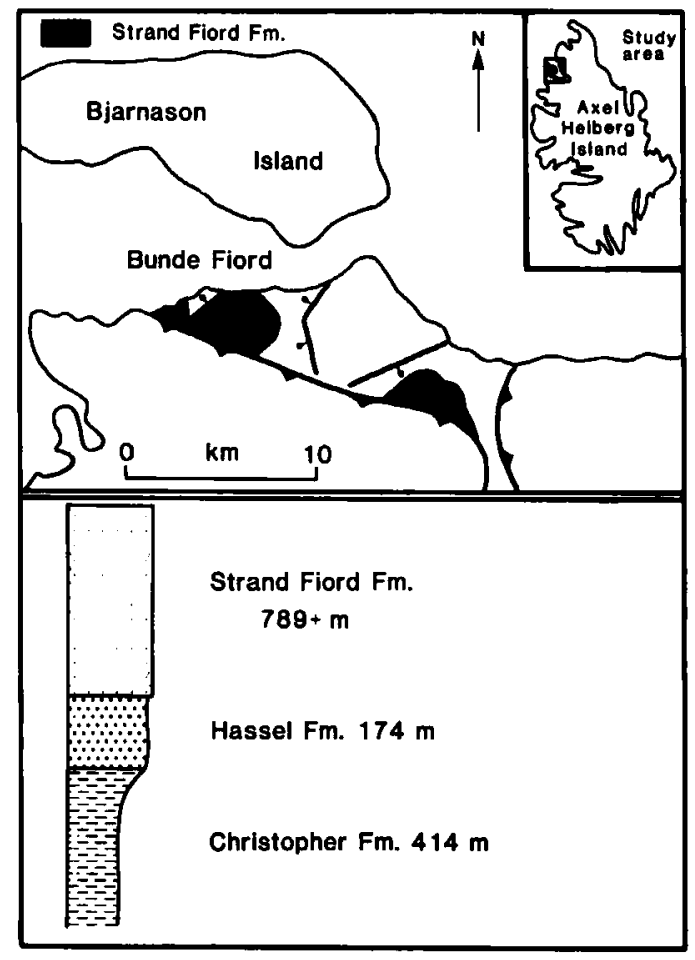

Fig. 4. Outcrop pattern of Strand Fiord Formation, Bunde Fiord area, northwestern Axel Heiberg Island and general stratigraphic column (from Thorsteinsson \& Trettin 1972 and unpublished data).

\section{Present work}

\section{Strand Fiord Formation}

Several sections of the Strand Fiord volcanics were measured along Kanguk Peninsula and the north side of Expedition Fiord (Fig. 6). This work has confirmed the observations of J. G. Souther and others (in Fortier et al. 1963) wherein the sequence thins towards the east; the southern limit of exposure is the head of Strand Fiord where the volcanics range in thickness from $100 \mathrm{~m}$ to $137 \mathrm{~m}$. On the south side of Strand Fiord the volcanic sequence also thins to only a few tens of metres; at Glacier Fiord on south Axel Heiberg, basalt flows and agglomerates are absent and the equivalent stratigraphic interval is occupied by a thin sandstone.

Ninety per cent of the volcanic sequence consists of thick lava flows that have conspicuous columnar jointing. The remaining $10 \%$ is made up of a variety of volcaniclastic conglomerates, sand-

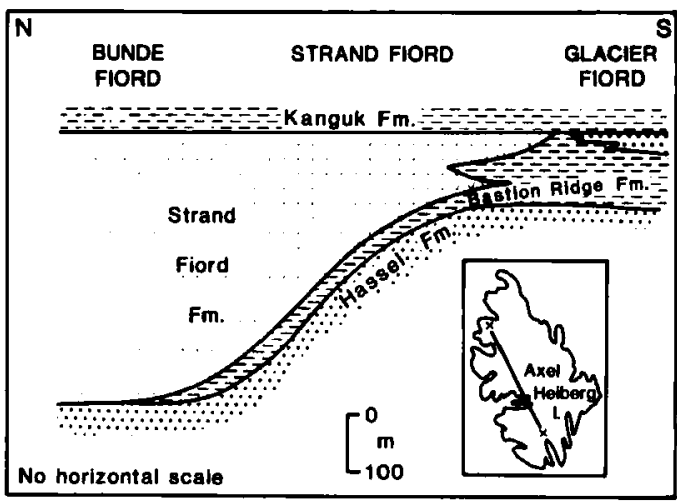

Fig. 5. North-south stratigraphic cross-section of Strand Fiord Formation, western Axel Heiberg Island.

stones and argillites, and rare coal seams. However, individual measured sections exhibit considerable variation in the volcanic and volcaniclastic components. On west Kanguk Peninsula and Expedition Fiord (sections 1, 2 and 3, Fig. 6), volcaniclastics account for less than $10 \%$ of the total thickness, whereas in the thinner eastern sections this value ranges from $30 \%$ to $50 \%$. In addition, there is a concomitant change in the style of sedimentation, from mainly laharic breccia and agglomerate in western exposures, to a variety of breccia and reworked conglomerate, sandstone and mudrock lithologies in the east (Fig. 7). Details of the various volcanic and volcaniclastic facies are provided in the following sections.

Within this stratigraphic framework we define two principal facies types: volcanic facies that are the products of lava extrusion, and volcaniclastic facies that resulted from direct deposition or reworking of volcanic debris in air and water. This last category includes rocks of true (pyroclastic) airfall origin as well as epiclastic varieties.

\section{Bunde Fiord area}

In the summer of 1983 detailed geologic mapping was carried out in the Bunde Fiord area of northwestern Axel Heiberg Island. Two detailed stratigraphic sections were measured and the Christopher, Hassel and Strand Fiord Formations were identified (Fig. 4) within strata previously mapped as Christopher Formation (Thorsteinsson \& Trettin 1972). The Hassel Formation which had not previously been recognized in this area consists 


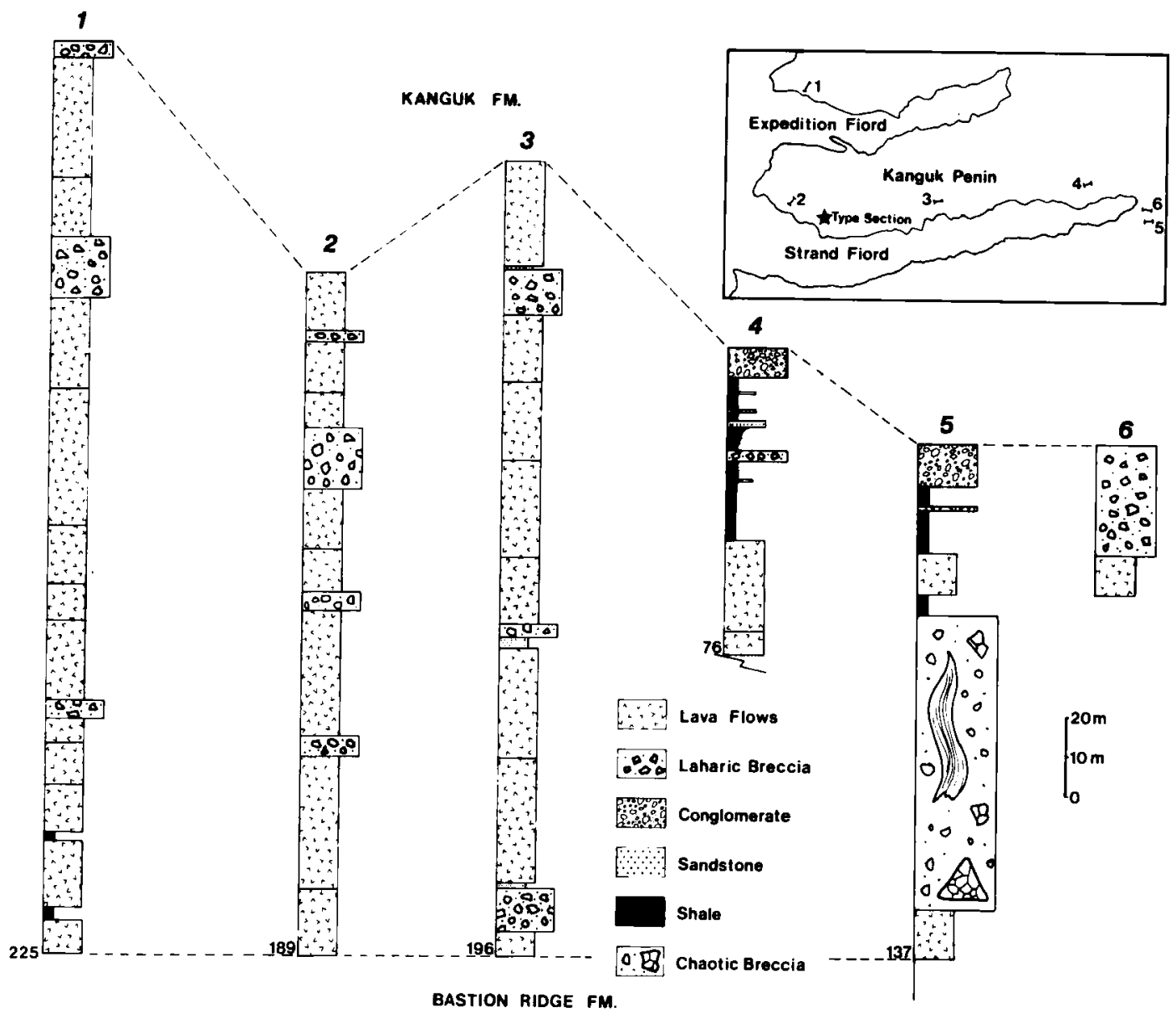

Fig. 6. A schematic representation of measured sections through the Strand Fiord volcanics in the Kanguk Peninsula area. Map inset shows section locations.

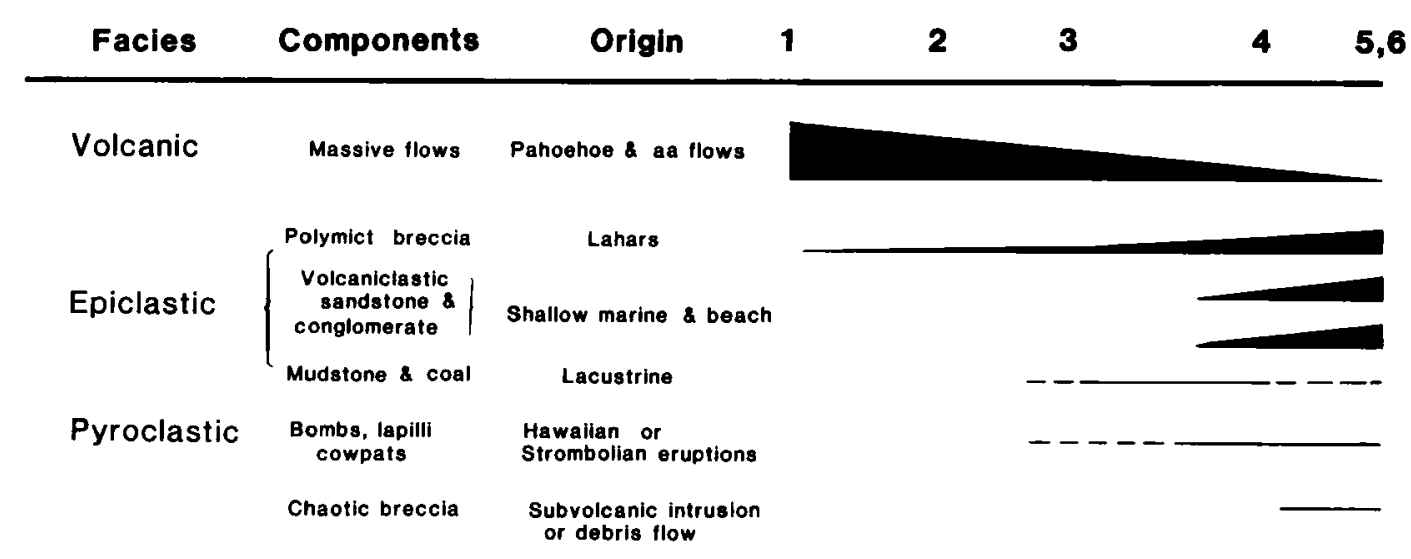

Fig. 7. The relative proportions of each of the volcanic, epiclastic and pyroclastic facies, observed in measured sections in the Kanguk Peninsula area. The increase in various epiclastic facies in eastern sections is clearly demonstrated. 
of $17 \mathrm{~m}$ of fine-grained, burrowed sandstone of marine shelf origin and thus is very similar in thickness and lithology to Hassel strata in the Strand Fiord area. The Hassel Formation at Bunde Fiord is overlain by a thick succession of basaltic flows $(789+\mathrm{m})$ which on the basis of lithology and stratigraphic position is placed in the Strand Fiord Formation. The top of the Strand Fiord Formation is everywhere in thrust fault contact with Carboniferous evaporite and carbonate strata. The Strand Fiord Formation at Bunde Fiord differs from that of the Strand Fiord area in that it is much thicker and consists entirely of non-marine flow units which often have red weathering, scorriaceous tops.

\section{Original distribution of Strand Fiord volcanics}

The interpreted original distribution of the Strand Fiord volcanics in the Sverdrup Basin is illustrated in Figure 8. Upper Cretaceous strata are not widely preserved in the basin making this interpretation rather speculative. The southern and western limits are reasonably controlled but the extent of the volcanics to the northeast is unknown. Our interpretation for this area is based on the presence of north-trending Cretaceous dyke swarms on northeastern Axel Heiberg Island and adjacent Ellesmere Island (Fig. 8). Overall it appears that the Strand Fiord volcanics formed a southward tapering wedge centred on Axel Heiberg Island.

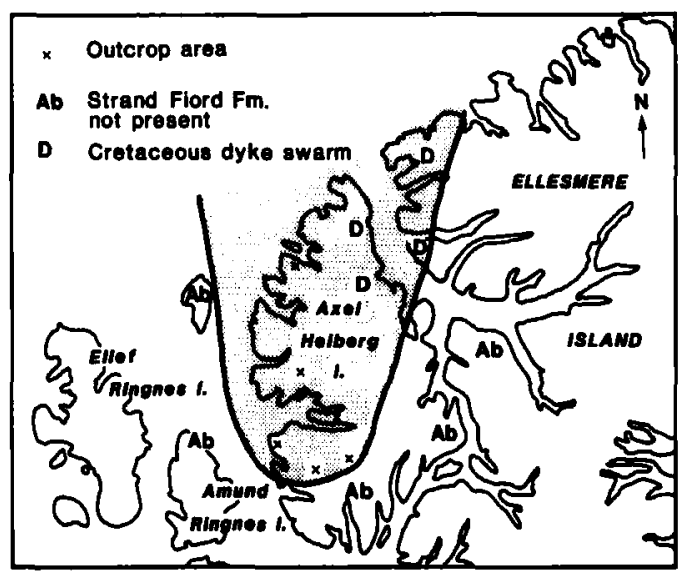

Fig. 8. Interpreted, original distribution of the Strand Fiord volcanics. The former presence of the formation on northeastern Axel Heiberg Island and the northwestern tip of Ellesmere Island is based on the occurrence of north trending, Cretaceous dyke swarms in these areas.

\section{Description of volcanic facies}

\section{Lava flows}

Basalt lava flows are the major constituent of the Strand Fiord volcanics, individual flows ranging in thickness from $6 \mathrm{~m}$ to $60 \mathrm{~m}$. Most flows contain conspicuous columnar jointing and the various patterns of joints enable recognition of cooling units. At Strand Fiord, flows are made up of one, two or three cooling units. Thick subaerial flows at Bunde Fiord are generally composed of only a single cooling unit; thick, red weathered scorria commonly marks the top of flow units, making their identification a simple task. The range of flow thicknesses at the two localities is similar in magnitude. The flows at Bunde Fiord are consistently near the upper limit of the observed thicknesses $(35-60 \mathrm{~m})$ while flows at Strand Fiord rarely exceed $35 \mathrm{~m}$ in thickness.

Flow bases are usually abrupt and non-brecciated. In some cases at Strand Fiord small, millimetre-sized amygdules at flow bases are usually associated with subjacent fine-grained volcaniclastics that presumably were wet; the amygdules formed upon injection of superheated steam into the base of the flow. Some good examples of injection structures were seen at the head of Strand Fiord where lava flows are in contact with Bastion Ridge Formation shales. Unfortunately no cylindrical flow-base vesicles were found that might have given indications of flow direction.

The tops of flows are commonly abrupt and contain amygdules that account for between $10 \%$ and $40 \%$ by volume of the rock in the upper metre of each flow at Strand Fiord and the upper 1-7 $\mathrm{m}$ of each flow at Bunde Fiord. Amygdules have spherical or oblate geometries with long axes up to $1-2 \mathrm{~cm}$, or in rare cases are much larger cavities up to $12 \mathrm{~cm}$ long. The direction of elongation in most cases parallels the tops of flows as a result of stretching vesicles prior to complete freezing of the lava. Amygdules usually are lined with chlorite and filled by coarse calcite spar or chalcedony. Despite the similar development of amygdular flow tops at both localities, only at Bunde Fiord is red weathered scorria extensively developed. On recently weathered surfaces dissolution of the amygdules gives the appearance of 'original vesicularity in the basalts'.

In the Strand Fiord area brecciated flow tops also occur and these are of two types:

(1) Highly irregular fracture patterns may occur 
Fig. 9. A fine example of twofold subdivision of a basalt flow from Section 5 at the head of Strand Fiord. The lower colonnade (lc-overlying Bastion Ridge shale- $\mathrm{Br}$ ) contains coarse columns up to a metre across, and grades into the upper, finer entablature (E) with chevron joint patterns. The contact (arrows) between the colonnade and entablature is gradational over about a metre and parallels the undulations at the base of the flow. Total flow thickness is 15 metres. The flow is overlain by Chaotic Breccia.

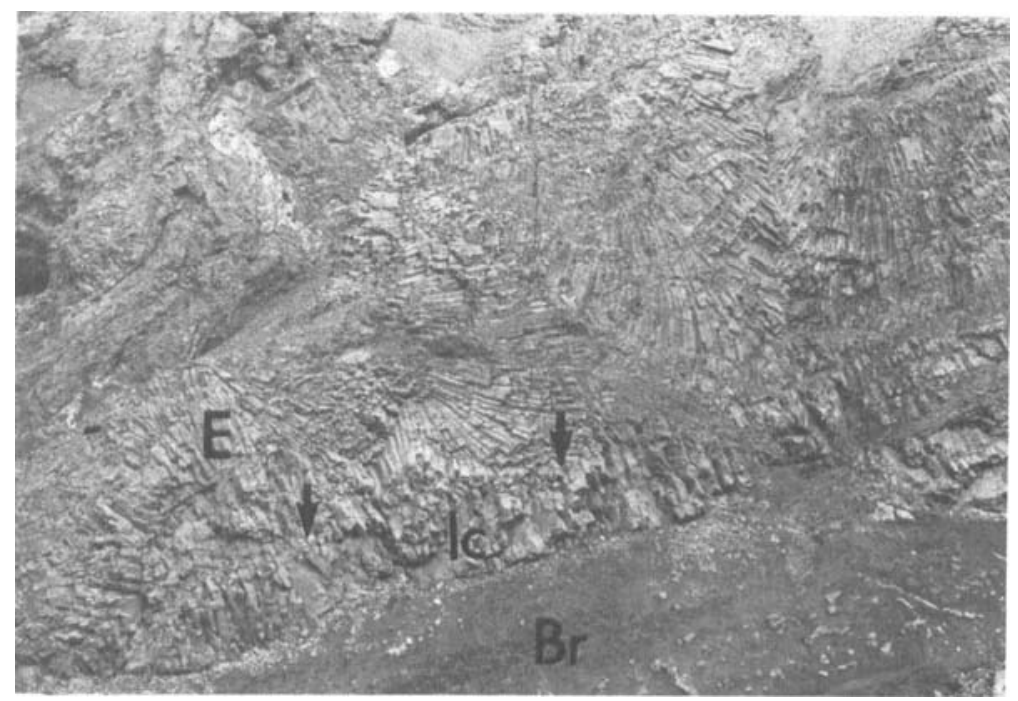

in the upper 2-5 m, wherein individual basalt blocks are tight fitting polyhedra and displaced by only a few centimetres. The blocks commonly are amygdaloidal.

(2) A different style of breccia, commonly referred to as agglomerate, is seen as monomict, very poorly sorted, highly angular to spinose, amygdaloidal basalt blocks that are completely displaced and disoriented. Blocks containing a high proportion of amygdules $(50 \%)$ often have more spinose outlines. Interstitial matrix or groundmass consists of all size grades of basaltic debris. Fracture and void-filling calcite or chlorite are common. In some flows there is complete gradation between the two breccia types where highly fractured, but only slightly displaced basalt changes upwards to poorly sorted flow-top breccia.

In his excellent account of basalt lavas in the Giant's Causeway, Northern Ireland, Tomkeieff (1940) observed a two-fold subdivision of individual flows; a lower colonnade and an upper entablature - terms that Tomkeieff borrowed from classical architecture. The colonnade refers to an interval containing regularly spaced, relatively straight joints that are perpendicular to the flow surface, whereas the entablature refers to a highly curved pattern of joints. Spry (1961) later recognized that many flows contain a three-fold subdivision with an upper and lower colonnade, and a central entablature.
Flows of the Strand Fiord Formation contain both the two-fold and three-fold arrangements, and some spectacular examples can be seen along Kanguk Peninsula, Dragon Cliffs along north Expedition Fiord, and at the head of Strand Fiord (Fig. 9). Colonnade joints are usually five or six sided and have cross-sectional widths averaging $40-60 \mathrm{~cm}$, occasionally reaching $120 \mathrm{~cm}$. Crossjoints, that form at right angles to the prism facies, also are common (Fig. 10). The medial entablature consists of joints that are slightly curved, to complex chevron patterns that are upright, inverted or oblique (terms after Spry 1961), and attain thicknesses of up to $15 \mathrm{~m}$. Contact between the lower colonnade and entablature commonly is abrupt, with a marked decrease in column size in the latter. However, despite this change in column size and orientation there is no concomitant change in texture (grain size) or composition of the basalt; the contact is defined on the change in joint habit alone. This also applies to the upper colonnade - entablature contact although columns in the upper unit usually have much smaller dimensions.

\section{Volcaniclastic facies}

Four major volcaniclastic facies are recognized here, each having distinct sedimentologic characteristics that are indicative of a wide spectrum of depositional mechanisms and environments. Both 


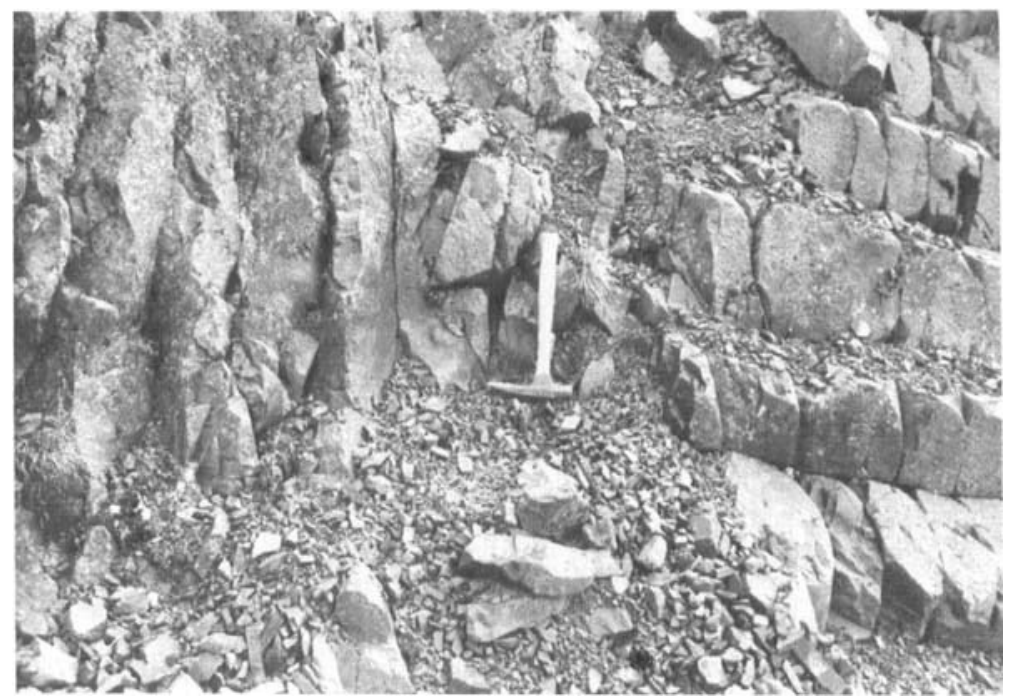

Fig. 10. A close up view of chevron entablature showing development of cross-joints. Section 3. Hammer is $33 \mathrm{~cm}$ long.

epiclastic and pyroclastic facies are recognized. Epiclastic facies consist of polymict volcanic breccias, volcanic conglomerate and sandstone and coaly mudrocks. Pyroclastic material of an airfall nature is also present.

Matrix supported polymict volcanic breccias that exhibit very poor sorting occur in tabular beds up to $15 \mathrm{~m}$ thick. Along Kanguk Peninsula these breccias are intercalated with lava flows and compose some $10-15 \%$ of the total volcanic sequence. Similar breccias occur at the head of Strand Fiord (Sections 5 and 6), although here they are located at the top of the sequence and are interbedded with volcanic sandstone, mudstone and conglomerate. Where the breccias are associated with volcanic flows, bed contacts are well defined. Bed contacts in breccias that are interbedded with other volcaniclastic rocks are recognized on the basis of abrupt changes in framework organization and clast size. However, some of the thick brecciaunits may be composite, for example at Section 6 (Fig. 11) where crude fining upwards sequences were noted. In this case individual breccias are one to three metres thick. Recognition of single breccia beds is further enhanced when separated by thin interbeds of

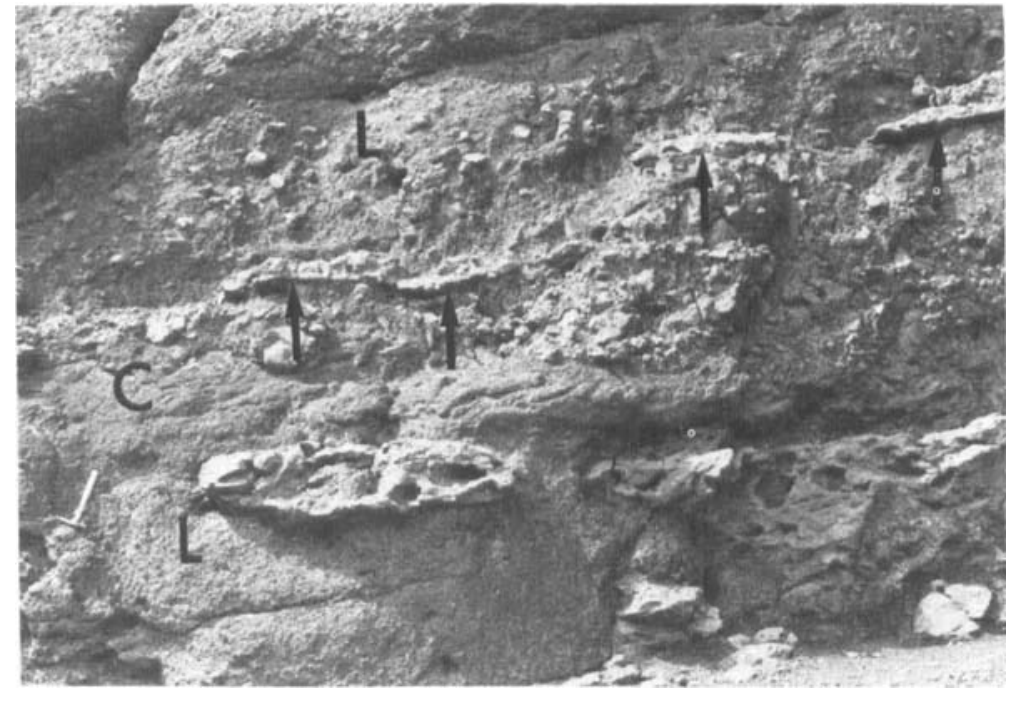

Fig. 11. Two polymict (laharic) breccia units (L), separated by an interval of cross-bedded lapillistone and reworked boulder conglomerate (C) and several cow-pat bombs (arrows). Note the irregular surface on top of the conglomerate bed and the curvature on the upper cowpats where they have moulded to the top of the conglomerate bed. Hammer is $33 \mathrm{~cm}$ long. Section 6. 
Fig. 12. Tabular bedded, clast supported conglomerate with rounded and subrounded cobbles of basalt. The degree of clast rounding contrasts markedly with that in the polymict breccias. A small lens (partly eroded) of volcaniclastic sandstone interfingers with the conglomerate on the lower left. Section. 5. Hammer is $33 \mathrm{~cm}$.

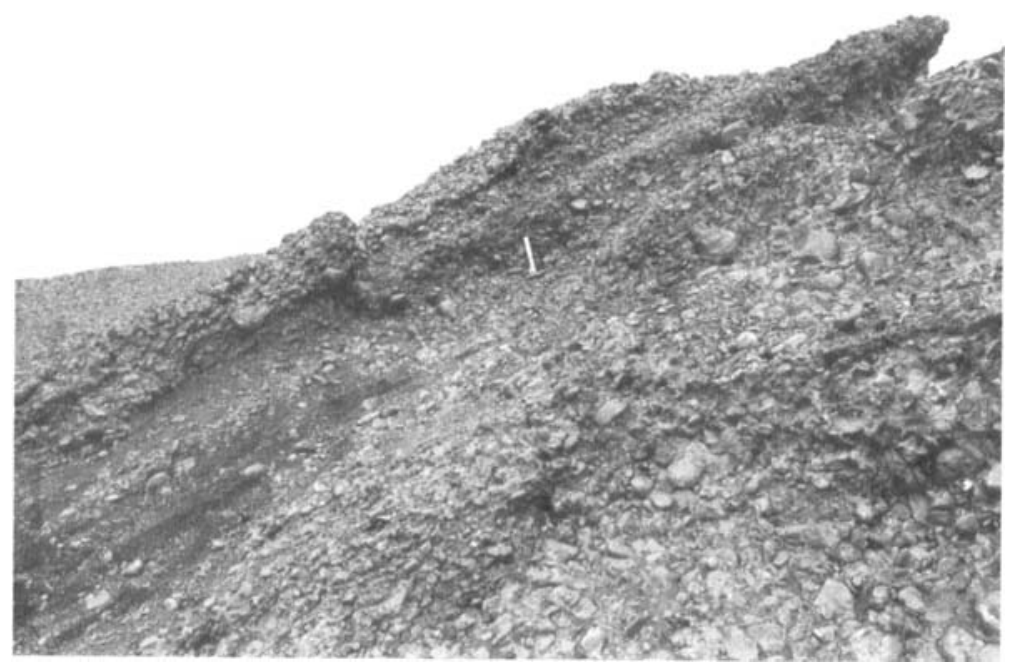

sandstone or pebbles with a clast-supported fabric. Some contacts show erosional relief of a metre and more. Framework clasts exhibit a wide range of roundness and composition. The clasts, occasionally up to $3 \mathrm{~m}$ across, consist of basalt with wide variation in vesicularity. Some blocks show relic columnar joint habit. A few lapilli-sized fragments have a brick-red colour and represent oxidized lava or reworked sediments. An important component of the breccias is coalified wood fragments, some a metre long.
Volcanic conglomerates and sandstones have only been observed along the thin, eastern edge of the volcanic sequence (Sections 4 and 5, Fig. 6 ), where they comprise about $10 \%$ of each measured section. The conglomerates occur as tabular beds and lenses $0.5-2 \mathrm{~m}$ thick, that are stacked into sequences up to $10 \mathrm{~m}$ thick. Individual beds also occur locally. Stratification within beds is uncommon except at Section 5 where low angle planar cross-beds were noted (Fig. 12). Tabular beds commonly are separated by thin sandstone

Fig. 13. A general view of tabular bedded conglomerate and dark grey siltstone-shale interbedded with think, coarsening upwards volcaniclastic sandstones (lower right). The conglomerate is about $10 \mathrm{~m}$ thick. Section 4

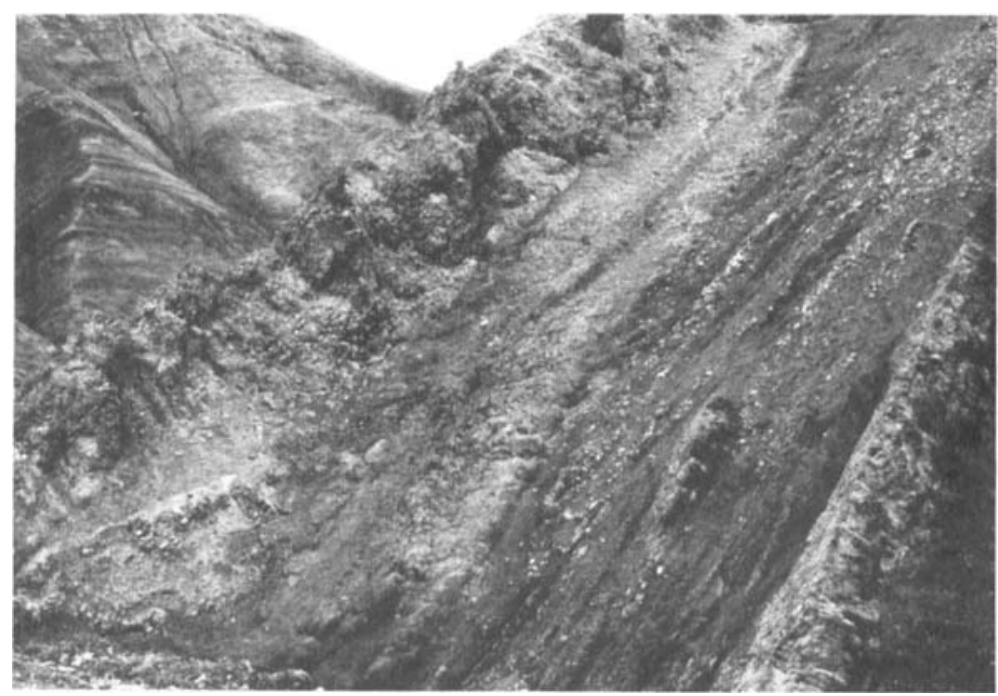


stringers or lenses which in turn contain small trough cross-beds and ripples.

Clast size varies considerably between beds, with averages ranging from $5 \mathrm{~cm}$ to $20 \mathrm{~cm}$. Sorting is poor to moderate. In contrast to the polymict breccias, the framework clasts are remarkably well rounded. One bed in particular noted in Section 5 along north Kanguk River, is $2.5 \mathrm{~m}$ thick, clast-supported and contains well rounded, subspherical basalt boulders reaching $80 \mathrm{~cm}$ in width set in a mudstone matrix. The size and degree of rounding suggests that the boulders may have originated as pyroclastic bombs that were subsequently reworked and abraided. Wood fragments are common in most of the conglomerates.

Like the conglomerates, volcaniclastic sandstones are generally restricted to eastern sections of the Strand Fiord Formation, and comprise less than $5 \%$ of this sequence. The sandstones have tabular and lensoid geometries, are usually less than a metre thick, and are interbedded with siltstone, shale and conglomerate (Fig. 13). A few of the sandstones form the upper units of coarsening-upwards sequences 1-2 $\mathrm{m}$ thick. Numerous silty sandstone beds near the top of Section 4 contain abundant leaf impressions including Metasequoia sp. and broadleaf species. The sandstones are moderately to poorly sorted and consist of subrounded clasts of fine grained basalt (35\%), abundant reworked volcaniclastic mudstone-siltstone $(60 \%)$, and some detrital chlorite $(5 \%)$. All components show pervasive chlorite alteration. The mudstone clasts also con-

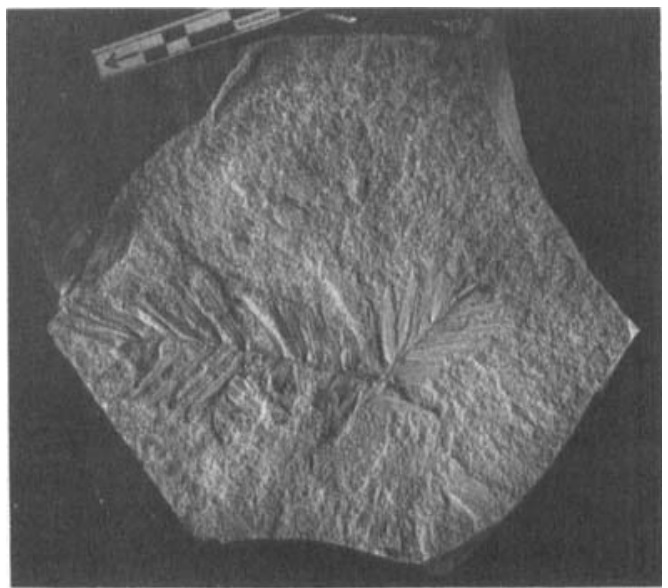

Fig. 14. Impression of Metasequoia in mudstone, associated with a thin coal bed and fresh water bivalves from Section 3 . tain a non-volcanic component of fine muscovite and very fine quartz, similar to shales of the Bastion Ridge and Kanguk Formations, and are probably of hemi-pelagic origin. Cementation of these sandstones proceeded in two stages: the first consists of an isopachous rim of fibrous chlorite, and a pore filling stage of bladed laumontite.

$A$ thin bed of shaly coal, no more than $5 \mathrm{~cm}$ thick was located at Section 3 and forms part of a 4-6 $\mathrm{m}$ thick unit that also contains brown mudstone, pebbly mudstone, very fine sandstone and a polymict breccia some three metres thick. The shaly coal and mudstone contain well preserved leaf impressions including Metasequoia sp. (Fig. 14) and broadleaf specimens, as well as abundant casts of small fresh water bivalves. The polymict breccia appears to intertongue with these finer grained lithologies. The entire $6 \mathrm{~m}$ sedimentary unit is sandwiched between thick, jointed lava flows.

Pyroclastic facies are represented by bomb and lapilli-sized volcanic clasts up to $10 \mathrm{~cm}$ in width and are scattered throughout the upper ten metres of the underlying Bastion Ridge Formation where they are 'suspended' in the silty shale host rock. These fragments do not conform to any type of bedding as noted in the case of bedded polymict breccia and boulder conglomerate. In Section 5 , the suspended clasts occur immediately below thick lava flows.

A different type of pyroclast was observed in Section 6 at the head of Strand Fiord, taking the form of markedly elongated fragments of basalt, attaining lengths of $120 \mathrm{~cm}$, but only $10-20 \mathrm{~cm}$ thick (Fig. 11). These fragments are oriented parallel to bedding and usually occur at contacts between successive polymict breccia or conglomerate beds within the Strand Fiord Formation. Some of the elongate fragments are also associated with spindle shaped bombs.

\section{Chaotic breccia facies}

A distinctive chaotic breccia that is $75 \mathrm{~m}$ thick, was found at only one locality near the head of Strand Fiord (Section 5). Both upper and lower contacts are relatively abrupt, but internally no coherent structure or layering could be discerned. The lower contact appears to cut down into the subjacent (joined) lava flow. The breccia consists of an ill sorted, chaotic jumble of basalt, tuffaceous sandstone and shale fragments that range in size from ash to blocks ten metres in width. 
Fig. 15. A vertical section of Chaotic Breccia, showing the massive size of locally derived, tuffaceous siltstone blocks (pale grey), and large blocks of jointed basalt (arrow). Geologist for scale at lower left. Section 5 .

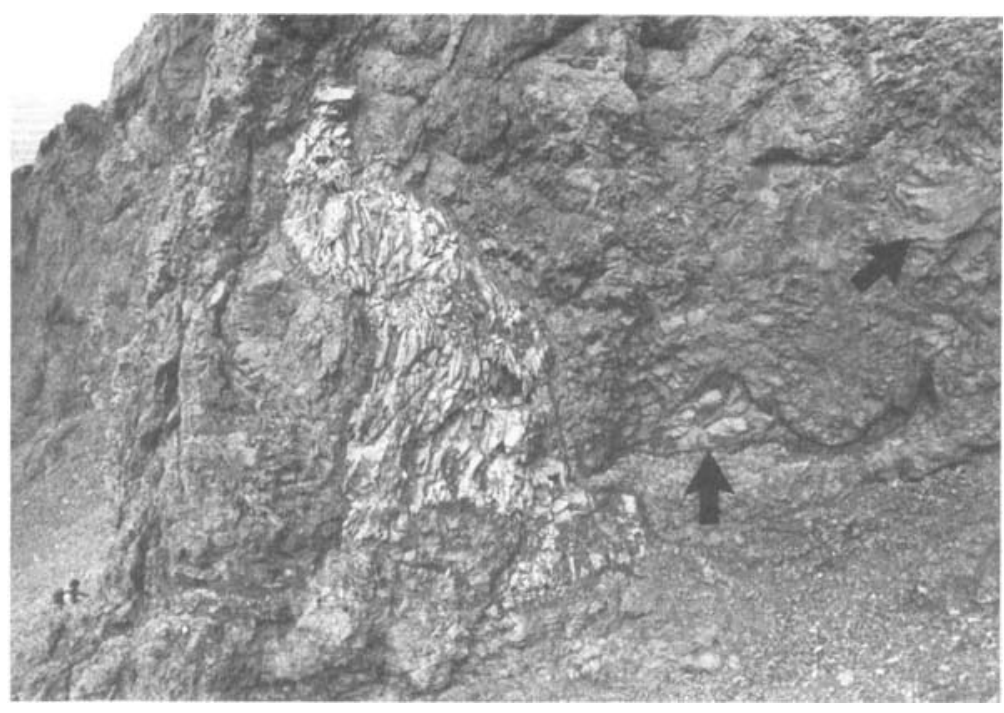

All of the fragments are highly angular. The basalt component predominates, making up to $90 \%$ of the breccia, and includes amygdaloidal and dense varieties; some of the larger blocks contain colonnade joint sets. Reworked tuffaceous sandstone blocks, up to $10 \mathrm{~m}$ wide are conspicuous because of their white-pale grey weathered surface (Fig. $15)$; primary layering within the sandstones is completely disoriented, and also contorted, indicating a degree of plasticity during reworking. Highly contorted inclusions of shale also occur, sometimes impregnated with fine basalt fragments. Features such as block size, absence of sedimentary layering and thickness, serve to distinguish this breccia from the polymict breccias. This breccia also lacks the muddy matrix that is common in polymict types.

\section{Dykes and sills}

Dykes and sills that intrude the Hassel and Christopher Formations are associated with Strand Fiord volcanism; intrusions do not occur in the overlying Kanguk or Eureka Sound Formations. Most of the intrusions are fine-grained and have textures and compositions similar to the Strand Fiord lava flows. A few coarse-grained gabbros also occur, and are characterized by ophitic textures of labradorite (up to $2.5 \mathrm{~mm}$ long) and pyroxene (augite); a pale green pleochroic clinopyroxene locally rims the colourless augite.

\section{Interpretation of facies}

In the type area thick, fine grained basalt flows that make up a major part of the Strand Fiord Formation, occur in two principal forms, namely the presence of brecciated or non-brecciated tops. Observations of recent lava flows, especially in Hawaii, indicate that such flows can originate in three ways, as pahoehoe, aa, or blocky forms, and all three types can be inferred for the Strand Fiord flows. Non-brecciated flows with abrupt tops correspond to pahoehoe types that form by flow of fluid lava and where freezing takes place without subsequent mass movement. Some of the brecciated units in the Strand Fiord that have polyhedral fragments are analogous to blocky flows, although there appears to be a complete gradation to breccias containing spinose fragments of lava, that are more likely aa-type flows. Lavas of this nature are believed to develop when the rate of shear (as a function of flow rate) exceeds some critical value of lava viscosity (Peterson \& Tilling 1980). In recent Hawaiian examples (from Mauna Loa and Kilauea volcanoes) all lava flows originate as pahoehoe types but can change to aa types downslope. The position of this transition in terms of distance from the issuing vent is quite variable, and can be correlated with effusion rate and cross-section area of the vent (see Walker 1973a; Malin 1980). The resulting stratigraphic sequence can result in 
variable proportions of pahoehoe and aa flows, as is the case for the Strand Fiord succession.

Lava flows in the Strand Fiord area overlie and in places interfinger with marine siltstones of the Bastion Ridge Formation, suggesting emplacement under subaqueous conditions. However, nowhere have pillow lavas formed. Because of the difficulties in correlating individual flow units between sections, we are not able to determine whether lavas at Strand Fiord were extruded subaerially and subsequently flowed into the sea, or if extrusion was subaqueous. That extensive lava flow sheets can develop under water is now well established, for example in the recent Galapagos Rift (Lonsdale 1977; Ballard et al. 1979) and also in some ancient volcanic complexes (e.g. Hargreaves \& Ayres 1979; Ricketts et al. 1982). Ballard et al. (1979) have suggested that such subaqueous sheet flows are analogous to subaerial surface-fed pahoehoe lava (i.e. non-channelized flows) whereas pillowed lavas are analogous to channelized tube-fed pahoehoe lavas. The absence of pillows in the Strand Fiord Formation leads us to speculate that these lavas also were extruded as surface-fed and subaqueous sheetflow lavas. The subaerial flow sequence at Bunde Fiord represents the extrusion of thick sheet flow lavas similar in mode of extrusion to flows at Strand Fiord but presumably near the centre of volcanic activity.

Pyroclastic ejecta in the form of lapilli and spindle shaped bombs are found suspended in Bastion Ridge shales which interfinger with and underlie the Strand Fiord Formation. Cow pat bombs also overlie some beds of polymict breccia. This type of debris is the product of relatively mild explosive eruptions. Cow pat bombs in particular are typical of weakly explosive Hawaiian and Strombolian activity (Walker 1973b) where ejected fiuid lava fragments within the eruption column, and 'spatters' upon contact with the ground.

Textural and compositional features of the polymict breccias are consistent with their interpretation as lahars. Large wood fragments in many of the lahars further indicate that fragmental debris probably accumulated in a subaerial environment, but this does not permit the distinction between subaerial or subaqueous deposition of the resulting debris flow. Thick, composite laharic breccia units exposed at the head of Strand Fiord contain veneers and thin beds of clast supported pebble conglomerate and cross- bedded sandstone that indicate local reworking of the tops of the debris flows. The cow pat bombs described in the previous section, provide evidence of subaerial deposition for at least some of the lahars.

Rapid facies changes in the volcaniclastics are evident in eastern sections of the Strand Fiord Formation. For example, as little as one kilometre separates exposures of thick, composite laharic breccias (Section 6) from stratigraphically equivalent conglomerates and sandstones containing low angle planar cross-beds (Section 5). Clast supported frameworks and the degree of pebble rounding in the latter are indicative of considerable reworking. Furthermore, a few of the volcanic sandstone beds form the upper units of thin, coarsening upwards sequences that are interbedded with siltstone and shale. These lithologies are interpreted as being of shallow marine origin, representing beach and shoreface environments. The intimate lateral association between these facies and the polymict breccias further suggests that debris transported to the shore by lahars has been reworked by waves or currents in a littoral or sublittoral setting.

The mudstone-coal facies, with its abundant leaf impressions and fresh water molluscs, is interpreted as lacustrine, where small ephemeral lakes were created when lahars or lava flows blocked the local drainage system. This facies is particularly important, despite its relatively localized distribution, because it illustrates that the volcanic edifice in the Strand Fiord area built up above sea level, and was exposed for a sufficient period of time to allow colonization by plants.

The composition of the volcaniclastic rocks indicates that the sole source of sand size and coarser sediment was volcanic. The only terrigenous component present is very fine, silt-sized quartz, feldspar and muscovite, similar to that found in the Bastion Ridge shales. None of the terrigenous quartz sand that makes up the underlying Hassel Formation, found its way into the Strand Fiord depositional system.

Interpretation of the chaotic breccia facies presents something of a dilemma; its thickness and massive clast size is far greater than any of the laharic breccias observed here, it lacks internal layering and appears to truncate the underlying lava flow. The polymict nature of the breccia precludes an origin by autobrecciation of lava. However, two other processes are known to be capable of transporting such coarse deposits. The 
first of these is by debris flow; mud slides containing very large blocks can be generated on relatively steep slopes (several degrees) at times of heavy rainfall. Subaerial debris flows tend to be channelized and the resulting deposits would be expected to have restricted areal distribution. Observations of recent subaerial debris flows indicate that slopes greater than $10-12^{\circ}$ are generally required to generate movement and accelerate the flow (Campbell 1975). Deposition of debris usually takes place when gradients fall below this value, but can vary according to the viscosity of the flow. To generate a deposit $75 \mathrm{~m}$ thick, however, implies that the source terrane had considerable relief, whereas the mild effusive style of volcanism envisaged for the Strand Fiord example is more likely to have produced a subdued topography.

An alternative explanation for the Chaotic Breccia facies, is that it represents a shallow, subsurface intrusive breccia, that subsequently was extruded as a brecciated flow. According to Parsons (1969) and Wright \& Bowes (1963) brecciation can occur as a result of subsurface explosions, or by fragmentation of magma and subsequent intrusion, in proximity to a volcanic vent. These breccias consist of juvenile magma and wall rock but little matrix. Parsons notes, however, that unless the original vent can be clearly defined (e.g. by vertical, cross cutting relationships), it is difficult to distinguish the resulting breccias from other epiclastic deposits such as lahars. Of prime importance in the present example is the discordant relationship between the breccia and adjacent strata, which at Strand Fiord amounts to only a few degrees: there is no direct evidence for a vent in this area. Given the evidence cited above, we feel that an unequivocal distinction between a massive debris flow origin and an intrusive breccia origin, cannot be made without further investigation.

\section{Petrography}

The Strand Fiord Formation has tholeiitic rock series affinities and this is corroborated by petrographic observations and chemical analyses which are at present restricted to samples collected in the type area. Flows are amygdaloidal to massive and commonly fine to very fine grained. The rocks are essentially composed of lath-shaped plagioclase (labradorite-andesine) and equant and interstitial clinopyroxene. Rare phenocrysts of augite form as ophitic intergrowths with plagioclase. Apatite and ore minerals are present as accessory phases. Commonly the samples are fresh, however, secondary alteration can be pervasive, especially accompanying amygdaloidal textures. Products of secondary alteration include chlorite, pyrite, chlorophaeite, and calcite. Amygdules are filled with combinations of fibrous chloride, coarse calcite, and chalcedony. Fricker (1963) reported that minor olivine was either present or replaced by chlorophaeite.

Relatively few chemical analyses are presently available (Table 1). They clearly indicate the subalkaline nature and tholeiitic affinities of these rocks (Fig. 16), consistent with observed modes of extrusion and mineralogy, and resemble tholeiitic icelandites. Of particular note is the tend-

Table 1 .

\begin{tabular}{|c|c|c|c|c|c|}
\hline $\begin{array}{l}\text { Sample \# } \\
\text { GSC No. }\end{array}$ & $\begin{array}{c}1 \\
112056\end{array}$ & $\begin{array}{c}2 \\
112144\end{array}$ & $\begin{array}{c}3 \\
112350\end{array}$ & $\begin{array}{c}4 \\
112412\end{array}$ & $\begin{array}{c}5 \\
112363\end{array}$ \\
\hline $\mathrm{SiO}_{2}$ & 50.2 & 49.1 & 50.4 & 50.3 & 50.4 \\
\hline $\mathrm{TiO}_{2}$ & 2.11 & 2.61 & 2.75 & 2.08 & 2.60 \\
\hline $\mathrm{Al}_{2} \mathrm{O}_{3}$ & 13.3 & 13.8 & 12.7 & 13.5 & 13.1 \\
\hline $\mathrm{Fe}_{2} \mathrm{O}_{3}$ & 4.1 & 5.7 & 2.6 & 8.7 & 5.7 \\
\hline $\mathrm{FeO}$ & 9.0 & 7.3 & 12.1 & 4.5 & 9.3 \\
\hline $\mathrm{MnO}$ & 0.20 & 0.22 & 0.25 & 0.21 & 0.22 \\
\hline $\mathrm{MgO}$ & 5.22 & 3.60 & 4.00 & 4.97 & 3.76 \\
\hline $\mathrm{CaO}$ & 10.3 & 10.4 & 8.75 & 10.4 & 9.32 \\
\hline $\mathrm{Na}_{2} \mathrm{O}$ & 1.7 & 2.3 & 1.8 & 1.8 & 1.9 \\
\hline $\mathrm{K}_{2} \mathrm{O}$ & 0.93 & 0.58 & 0.61 & 0.58 & 0.74 \\
\hline $\mathrm{H}_{2} \mathrm{O}$ & 1.6 & 1.5 & 1.9 & 1.7 & 2.3 \\
\hline $\mathrm{CO}_{2}$ & 0.1 & 1.7 & 0.1 & - & 0.1 \\
\hline $\mathrm{P}_{2} \mathrm{O}_{5}$ & 0.22 & 0.40 & 0.31 & 0.25 & 0.29 \\
\hline s & 0.08 & 0.29 & 0.05 & 0.03 & 0.04 \\
\hline Vol. & - & 0.11 & - & - & - \\
\hline Total & 99.0 & 99.4 & 98.5 & 99.2 & 98.1 \\
\hline \multicolumn{6}{|l|}{ Cation Norm } \\
\hline $\mathrm{Q}$ & 7.59 & 10.37 & 10.27 & 8.66 & 11.30 \\
\hline Or & 5.82 & 3.60 & 3.90 & 3.66 & 4.73 \\
\hline $\mathrm{Ab}$ & 16.15 & 21.68 & 17.48 & 17.23 & 18.44 \\
\hline An & 27.42 & 26.91 & 26.80 & 28.83 & 27.06 \\
\hline $\mathrm{Di}$ & 11.88 & 6.28 & 6.25 & 11.86 & 8.72 \\
\hline $\mathrm{He}$ & 7.69 & 4.32 & 7.58 & 7.69 & 7.44 \\
\hline En & 9.31 & 7.30 & 8.82 & 8.70 & 6.86 \\
\hline Fs & 6.03 & 5.01 & 10.70 & 5.64 & 5.86 \\
\hline Mt & 3.99 & 4.51 & 2.94 & 3.99 & 4.63 \\
\hline Il & 3.11 & 3.82 & 4.14 & 3.09 & 3.92 \\
\hline $\mathrm{Cr}$ & 0.01 & 0.02 & 0.01 & 0.02 & \\
\hline Ap & 0.49 & 0.88 & 0.70 & 0.56 & 0.66 \\
\hline Py & 0.22 & 0.79 & 0.14 & 0.08 & 0.11 \\
\hline \multirow[t]{2}{*}{$\mathrm{Cc}$} & 0.27 & 4.51 & 0.27 & - & 0.27 \\
\hline & IB & IB & IB & IB & IB \\
\hline
\end{tabular}

\#1 fine grained sills in Christopher Formation; \#2 gabbro sill in Christopher Formation; \#3, 4 and 5 fine grained flows in Strand Fiord Formation. IB - Icelandic tholeiite. 
- Strand Fiord Fm. This study

$\triangle$ Avg. Afar Stratold Serles Thol. Basalt, Mohr, 1083

- Avg. Ashangl Fm. Tholeiltic Basalt Mohr, 1983

- Avg. Hawailan Tholelitic Basalt, Macdonald, 1968

- Avg. Oceanic Tholelite Hyndman, 1872

a Avg. Continental Tholeilte Hyndman,1972
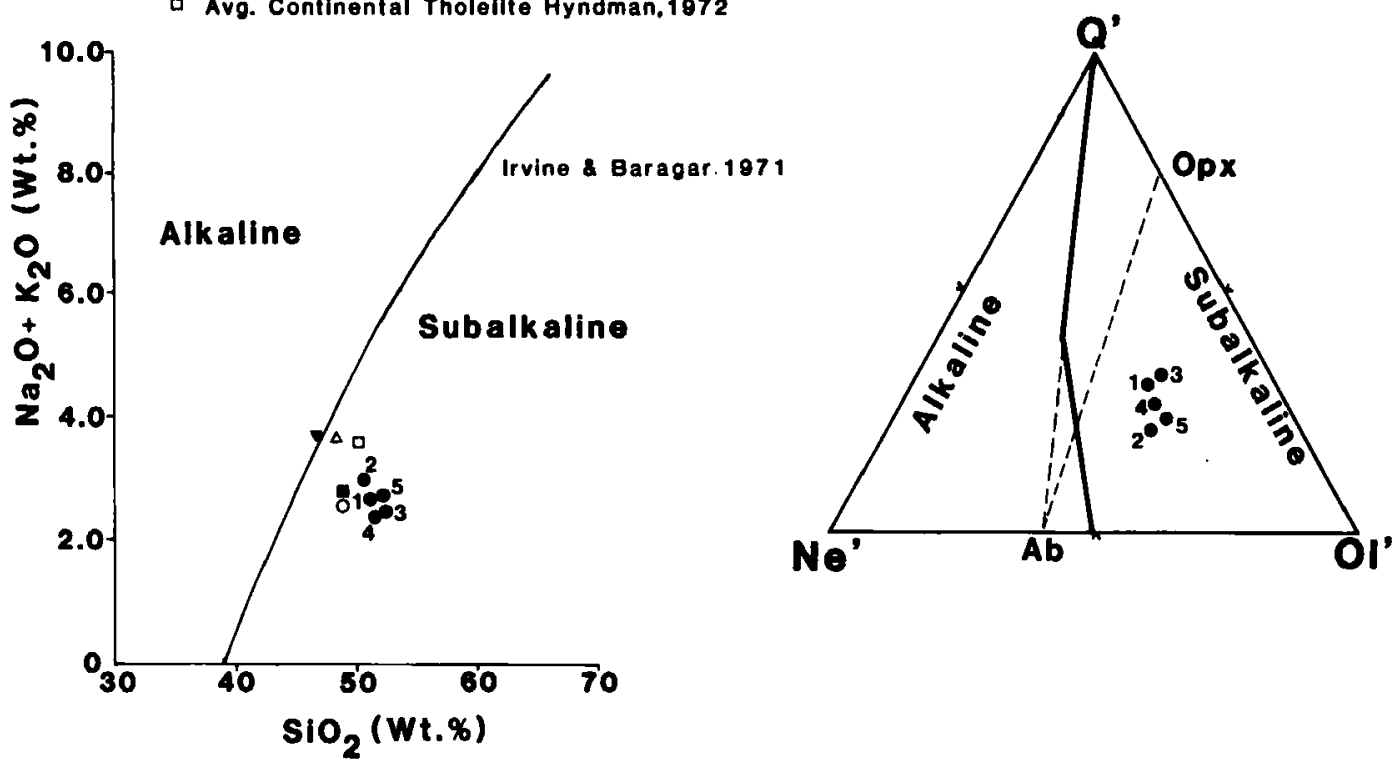

a

b

Fig. 16. (a) A silica-alkalies plot of the Strand Fiord Formation tholeitic basalts, and comparison with other major tholeiitic suites. The dividing line is from Irvine \& Baragar, 1971. (b) An $O l^{\prime}-N e^{\prime}-Q^{\prime}$ projection of Strand Fiord Formation basalts, based on per cent cation equivalents from the cation norm. Dividing line is from Irvine \& Baragar (1971).

ency of the rocks to be relatively enriched in titanium and iron.

\section{General interpretation of the Strand Fiord Formation}

The scenario of Fig. 17 depicts the styles of volcanic and related processes that gave rise to the Strand Fiord succession. This interpretation is based on the following criteria:

- southwards and eastwards thinning of the formation away from the Bunde Fiord and Strand Fiord areas; with

- a concomitant change in facies types, from predominantly thick, jointed lava flows in western and northern sections, to mixed lava flow and volcaniclastic rocks in the thinner eastern and southern sections;

- mainly subaerial lavas at Bunde Fiord, with subaerial and subaqueous lavas in the Strand
Fiord area where they interfinger with marine shales typical of the Bastion Ridge Formation.

The following discussion refers only to modes of extrusion and types of volcanic setting. No comparison of associated tectonic regimes is implied or should be inferred. The volcanic pile accumulated mostly by the quiet effusion of lavas, probably as extensive, non-channelized sheets of pahoehoe and aa flows. Presumably the source vents or fissures lay northwest of the two present areas of outcrop. The volcanic pile prograded towards the south and east. In the Strand Fiord area, accumulation was initially submarine but was rapid enough to eventually build above sea level. Surface weathering of the volcanoes occasionally produced laharic debris flows, some of which flowed into the sea. Ephemeral lakes formed when the local drainage was blocked by lahars or lava flows; the surface also was able to sustain some vegetation, including stands of Metasequoia. Along the shores of the volcanoes, 


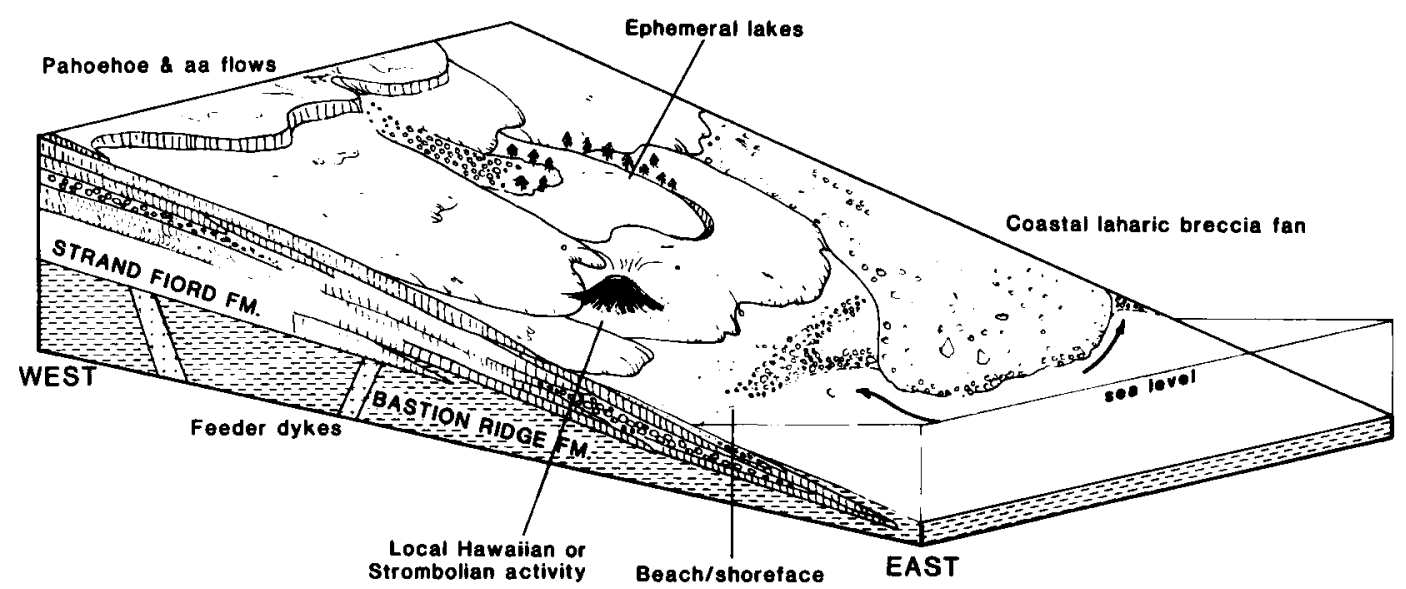

Fig. 17. A cartoon depicting the paleoenvironmental setting of the Strand Fiord volcanics, in the Strand Fiord area, representing sections 2-6 inclusive. The estimated paleogeographic distance from west to east is about 60 kilometres. The heavy arrows show transport of debris reworked from lahars to adjacent littoral environments.

waves eroded lava flows and reworked debris from laharic breccias, providing material for sand and boulder beaches that probably were very similar to modern coastal deposits found on the Canary, Galapagos and Hawaiian Islands. Mildly explosive Strombolian or Hawaiian eruptions occurred sporadically producing cow pat bombs and other ejecta that are now preserved on top of some laharic breccias, and in deeper water off-shore sediments. By considering down-dip variations in stratigraphic thickness of the volcanics (over a paleogeographic distance of $60 \mathrm{~km}$ along Kanguk Peninsula), it is apparent that the paleoslope of the volcanic edifice was low, probably only a few degrees. Features of the Strand Fiord volcanics such as their geometry (thinning to the east and south), their low paleoslope and style of volcanism, are typical of modern shield volcanoes found in a variety of volcano-tectonic regimes; examples include the continental rifts of East Africa, oceanic rifts (e.g. Iceland, Galapagos), or the well known mid-plate shields of Hawaii. Williams \& McBirney (1979) have described attributes to some of these shield volcanoes, noting that those of Iceland generally develop around central vent systems. In comparison, Hawaiian and Galapagos Island types also include fissure eruptions associated with small scale rifts, that are located radially or peripherally to the main vents. The principle source vents responsible for the bulk of the Strand Fiord volcanics probably lay north or northwest of Kanguk Peninsula and Bunde Fiord. Subsidiary vents or fissures also developed locally as evidence by the deposits of weakly explosive Strombolian or Hawaiian eruptions, and we tentatively conclude that shields of the Strand Fiord Formation were analogous to Hawaiian or Galapagos shields.

\section{Regional speculations}

The relationship of the Strand Fiord volcanics to the tectonic development of the Arctic region is necessarily very speculative due to our poor understanding of the evolution of the Arctic Ocean. The Strand Fiord Formation represents relatively quiet tholeiitic volcanism in an intraplate setting. The thickness and facies trends of the formation indicate that an extensive zone of volcanism extended southward from the Arctic Ocean margin to west-central Axel Heiberg Island in early Late Cretaceous. This cratonward dissipation of volcanism, perpendicular to the trend of the Sverdrup Basin suggests that the volcanic activity may be related to the evolution of the adjacent Arctic Ocean (Amerasian Basin) rather than to a local basin foundering event as suggested by Balkwill (1978). The timing and manner in which the Amerasian Basin formed is presently under dispute due to sparse data from the basin itself. The simplest and most quoted plate tectonic model which is based mainly on geological and geophysical observations from the basin margins is that the basin formed by the anti-clockwise rotation of northern Alaska and 
adjacent northeastern Siberia away from the Canadian Arctic Archipelago (Tailleur 1969; Rickwood 1970; Grantz et al. 1979). Sea floor spreading is interpreted to have begun in Early Cretaceous (Eittreim \& Grantz 1979) and to have lasted until early Late Cretaceous. Thus the Strand Fiord volcanism is coincident with the final phase of spreading.

The localization of early Late Cretaceous volcanism to the Axel Heiberg Island region and possibly northern Ellesmere Island region is also difficult to explain. Our present hypothesis is that the Strand Fiord volcanics represent the cratonward extension of the Alpha Ridge, a major crustal feature of presumed volcanic origin (Hall 1973) which trends northward from the continental margin north of Axel Heiberg and Ellesmere islands. The Alpha Ridge appears to represent a major localization of volcanism in the Amerasian Basin along a trend parallel to the spreading direction of the rotational model. The generally landward extension of this feature conveniently explains the localization of the Strand Fiord volcanism.

Acknowledgements. - The authors would like to thank the Geological Survey of Canada for promoting this study and allowing publication of the results. The Polar Continental Shelf Project provided much logistic help during the field season. Analyses in Table 1 were made by the Analytical Chemistry Section of Geological Survey of Canada, Ottawa, and CIPW norms were calculated by J. Maley. Claudia Thompson typed the manuscript and Elspeth Snow drafted the figures.

\section{References}

Balkwil, H. R. 1978: Evolution of Sverdrup Basin. Am. Assoc. Petrol. Geol. Bull. 62, 1004-1028.

Balkwill, H. R. 1983: Geology of Amund Ringnes, Cornwall, and Haig-Thomas Islands, District of Franklin. Geol. Surv. Can. Mem. 390.

Ballard, R. D., Holcomb, R. T. \& Van Andel, T. H. 1979: The Galapagos Rift at $86^{\circ} \mathrm{W}: 3$. Sheet flows, collapse pits and lava lakes of the rift valley. J. Geophys. Res. $84(B 10)$, 5407-5422.

Campbell, R. H. 1975: Soil slips, debris flows, and rainstorms in the Santa Monica Mountains and Vicinity, Southern California. U.S. Geol. Surv. Prof. Pap. 851.

Eittreim, S. \& Grantz, A. 1979: CDP seismic sections of westem Beaufort continental margin. Tectonophysics 59, 251-262.

Fortier, Y. O., Blackadar, R. G., Glenister, B. F., Greiner, H. R., McLaren, D. J., McMillan, N. J., Norris, A. W., Roots, E. F., Souther, J. G., Thorsteinsson, R. \& Tozer, E. T. 1963: Geology of the north-central part of the Arctic Archipelago, Northwest Territories (Operation Franklin). Geol. Surv. Can. Mem. 320.

Fricker, P. E. 1963: Geology of the Expedition area, Western Central Axel Heiberg Island Research Reports, McGill University, Montreal. Geology 1 .
Grantz, A. Eittreim, S. \& Dinter, D. A. 1979: Geology and tectonic development of the continental margin north of Alaska. Tectonophysics. 51, 263-291.

Hall, J. K. 1973: Geophysical evidence for ancient sea-floor spreading from Alpha Cordillera and Mendeleev Ridge. In Pitcher, M. (ed.): Arctic Geology. Am. Assoc. Pet. Geol. Mem. 19, 524-561.

Hargreaves, R. \& Ayres, L. D. 1979: Morphology of Archean metabasalt flows, Utik Lake, Manitoba. Can. J. Earth Sci. $16,1452-1466$.

Hyndman, D. W. 1972: Petrology of Igneous and Metamorphic Rocks. McGraw-Hill, New York, 533 pp.

Irvine, T.N. \& Baragar, R. A. 1971: A guide to the classification of the common volcanic rocks. Can. J. Earth Sci. 8, 523-548.

Lonsdale, P. 1977. Abyssal pahoehoe with laval coils at the Galapagos Rift. Geology 5, 147-152.

MacDonald, G. A. 1968: Composition and origin of Hawaiian lavas. Geol. Soc. Am. Mem. 116, 477-522.

Malin, M. C. 1980: Lengths of Hawaiian flows. Geology 8, 306-308.

Mohr, P. 1983: Ethiopian flood basalt province. Nature 303, 577-584.

Parsons, W. H. 1969. Criteria for the recognition of volcanic breccias: review. Geol. Soc. Am. Mem. 115, 263-304.

Peterson, D. W. \& Tilling, R. I. 1980: Transition of basaltic lava from pahoehoe to aa, Kilaauea Volcano, Hawaii: Field observations and key factors. J. Volcanol. and Georherm. Res. 7, 271-293.

Ricketts, B. D., Ware, M. J. \& Donaldson, J. A. 1982: Volcaniclastic rocks and volcaniclastic facies in the Middle Precambrian (Aphebian) Belcher Group, Northwest Territories, Canada. Can. J. Earth Sci. 19, 1275-1294.

Rickwood, F. K. 1970: The Prudhoe Bay field. In Proceeding of the Geological Seminar on the North Slope of Alaska, Pacific section. In Adkison, W. L. \& Brosge, M. M. (eds.): Am. Assoc. Petrol. Geol. L1-L11.

Souther, J. G. 1963: Geological traverse across Axel Heiberg Island from Bucharan Lake to Strand Fiord. Geol. Surv. Can. Mem. 320, 426-448.

Spry, A. 1961: The origin of columnar jointing, particularly in basalt flows. J. Geol. Soc. Aust. 8, 191-216.

Tailleur, I. L. 1969: Rifting speculation on the geology of Alaska's North Slope. Oil and Gas J. 67, 128-130.

Thorsteinsson, R. 1971a: Geology, Middle Fiord. Geol. Surv. Can. Map 1299A.

Thorsteinsson, R. 1971b: Geology, Strand Fiord. Geol. Surv. Can. Map 1301A.

Thorsteinsson, R. 1971c: Geology, Haig-Thomas Island. Geol. Surv. Can. Map 1303A.

Thorsteinsson, R. 1971d: Geology, Glacier Fiord. Geol. Surv. Can. Map 1304A.

Thorsteinsson, R. and Trettin, H. P. 1972: Geology, Bukken Fiord. Geol. Surv. Can. Map 1310.

Tomkeieff, S. I. 1940: The basalt lavas of the Giants Causeway district of Northern Ireland. Bull Volcanologique 6, 89-143.

Tozer, E. T. 1963: Mesozoic and Tertiary stratigraphy, western Ellesmere Island and Axel Heiberg Island, District of Franklin. Geol. Surv. Can. Pap. 63-30.

Walker, G. P. L. 1973a: Lengths of flows. Philos. Trans. R. Soc. Lond. A274, 107-118.

Walker, G. P. L. 1973b: Explosive eruptions - a new classification scheme. Geol. Rundsch. 62, 431-446.

Wright, A. E. \& Bowes, d.R. 1963: Classification of volcanic breccias: A discussion. Geol. Soc. Am. Bull. 74, 79-86.

Williams \& McBinney 1979: 